\title{
BETWEEN ECLECTICISM AND UNIQUENESS: A FEW REMARKS ON CONSTITUTIONAL SYSTEMS OF ASEAN COUNTRIES FROM THE PERSPECTIVE OF A POLISH COMPARATIVE CONSTITUTIONALIST
}

In a globalized world, knowledge of the peoples and countries of the proximal and the further neighborhood is an essential component of a comprehensive and thorough education. For scholars of comparative constitutional law, an essential element of deepening current knowledge is exploring new research directions and continuing to raise awareness of the organization and functioning of the modern states and processes of their evolution. Fully legal and comparative research requires not only professional competence in foreign languages, but also mastering the methods of such research, and above all the use of stays of foreign internships and numerous discussions with experts from other countries. It is impossible to carry out such studies based solely on, even the most carefully collected foreign legal material and normative literature. It is obvious that unseen but neither unknown nor uncontested, the invisible constitution raises serious challenges for constitutional design, constitutional interpretation and constitutional change. ${ }^{1}$ This perspective - that cannot be omitted leaves the researcher asking foundational questions about the nature of higher law, the limits of codification, and the necessary and sufficient conditions for constitutionalism - the essential issues of fully complete study in comparative constitutional law.

The aim of this article is to present in a broader research perspective the results, conclusions and experiences gained during research carried out in 2014-2017 under a grant financed by the National Science Centre granted on the basis of Decision DEC-2013/09/D/HS5/04458 in connection with the implementation of the project "The importance of the principle of bicameralism in the practice of parliamentary democracy Southeast Asia." The core result of this research was the publication of two monographs: Constitutional systems of selected countries of Southeast Asia: Singapore, Malaysia, Thailand, Timor-Leste (Lódź 2018) and The importance of the principle of bicameralism in the political practice of selected democracies of Southeast Asia Malaysia,

ORCID: 0000-0001-7430-5817, DOI: 10.4467/23538724GS.20.017.12135

1 R. Dixon, A. Stone, Introduction: the invisible constitution in comparative perspective [in:] The Invisible Constitution in Comparative Perspective, eds. R. Dixon, A. Stone, Cambridge 2019, pp. 3-20. 
Singapore, Thailand, East Timor) (Lódź 2019). These two monographs however - due to the assumed research objectives - were of a contributing and fragmentary nature and were concentrated on the issue of parliamentarism. Only further comparative studies can fully contribute to examining the constitutionalism of Southeast Asian countries to the extent that the constitutional systems of the Atlantic region countries are known to Polish researchers.

\section{The directions of Polish comparative research in the field of constitutional law}

There is no doubt that comparative constitutional law has enjoyed a certain renaissance since the mid-1980s. ${ }^{2}$ In particular, this period brought in Central and Eastern Europe political changes whose consequences have dominated research directions for Polish scholars of comparative constitutional law. The issue of transformation, evaluation of operating political systems in Europe in terms of their possible adaptation to Polish law, and finally, an analysis of the solutions were the backbone of the work of Polish constitutional researchers after 1989 transformation. At the same time in their work they usually reached for the "classical" (treated as the best, suitable and worth implementing) western models.

On the other hand, the adoption of the Constitution in 1997 allowed Polish constitutionalists to sail out into the broad currents of the issues of world constitutionalism, undertaking its important issues in a scientific manner through the prism of Polish institutions. The new Constitution, due to its detailed structure and coverage of many issues that remained outside the constitutional regulation so far (also in the field of other branches of dogmatics of law) gave impetus to the development of studies devoted to the analysis of the provisions of the constitution, constitutional institutions in their entirety and the practice of their functioning, also in context of theoretical dilemmas. Inevitably, comparative research in the first years of the Constitution of 1997 remained in the background, which was noted in 2010 during the Committee on Legal Sciences of the Polish Academy of Sciences. ${ }^{3}$ In my opinion, the accession of Poland to the European Union and the need to recognize the effects of this process on the basis of constitutional law, in the context of the multicentricity of the Polish legal system, are not without significance for this state of affairs.

The next turning point in the development of Polish constitutional law was the year of 2015 and a combined presidential and parliamentary victory of the populist

2 R. Hirschl, From comparative constitutional law to comparative constitutional studies, "International Journal of Constitutional Law" 2013, vol. 11, issue 1, pp. 1-12.

3 P. Sarnecki, Stan nauki prawa konstytucyjnego w Polsce, "Państwo i Prawo" 2010, z. 7, passim. 
Law and Justice party [PiS] began a series of deep political and legal changes which turned the constitutional order on its head in many respects. ${ }^{4}$ Since then, representatives of the science of constitutional law have dealt with the interpretation of the actions of the president, government and parliamentary majority in the context of assessing their compliance with the constitution. It should be added that convincing the majority of these actions led to a change in the constitution outside the formal legislative procedures. ${ }^{5}$

In English literature on the subject the term "invisible constitution" is used. ${ }^{6}$ The authors use this term when discussing non-normative factors relevant to the functioning, application and interpretation of the constitution. Nowadays in Poland we are also dealing with an invisible constitution. However, contrary to the aforementioned meaning, the constitution is invisible in Poland, because both the politicians of the ruling party (and, as it turns out, opposition politicians) with great ease propose to circumvent or actually circumvent its regulations.

Representatives of the constitutionalist community cannot remain indifferent to these changes, which means that comparative research in Poland goes to the background, and Polish science returns to the discussion of indisputable constitutional values, i.e. the principle of a democratic rule of law, equality and universality of electoral rights, and independence of judges.

Among other things for these reasons in the Polish science of constitutional law, the systems of Southeast Asian states have been neglected so far. At the moment there is no complete or partial publication on the political systems and constitutional practice of all Southeast Asian countries.

It can be seen however, that political scientists, who are particularly interested in the democratic changes taking place there, are interested in the political systems of the region. Among this group of researchers, the works of Krzysztof Gawlikowski, Adam W. Jelonek and Ewa Trojnar, Marek Bankowicz and Maria Ochwat deserve special attention. At the same time, constantly emerging scientific centres involved in research on this geographical area confirm the thesis about the growing interest of Polish scientists in the East Asian direction (e.g. Centre for East Asian Studies of

\footnotetext{
4 W. Sadurski, How Democracy Dies (in Poland): A Case Study of Anti-Constitutional Populist Backsliding (January 17, 2018). "Sydney Law School Research Paper No. 18/01", https://ssrn.com/abstract $=3103491$ or http://dx.doi.org/10.2139/ssrn.3103491 (accessed: 16.04.2020).

5 A. Michalak, 10 actions of politicians that changed Polish constitution without amending it (in preparation).

${ }^{6}$ In their publication, R. Dixon and A. Stone defined the invisible constitutions as: "Constitutions worldwide inevitably have 'invisible' features: they have silences and lacunae, unwritten or conventional underpinnings, and social and political dimensions not apparent to certain observers $(\ldots)$ these dimensions have role in the interpretation, legitimacy and stability of different constitutional systems."
} 
the University of Gdańsk, ${ }^{7}$ Asia-Pacific Research Center at the Wroclaw University of Economics and Business, ${ }^{8}$ Center for East Asian Civilization at SWPS University of Social Sciences and Humanities, ${ }^{9}$ Department of East Asian Studies - a unit of the Institute of International Studies at the Faculty of International and Political Studies of the University of Lódź, ${ }^{10}$ Center for Asian Affairs of the University of Lódź, ${ }^{11}$ Center for Asian and Pacific Research of the Institute of Political Studies of the Polish Academy of Sciences ${ }^{12}$ ), Center for Poland-Asia Studies. ${ }^{13}$ However, these centres do not conduct research on the legal aspects of constitutional orders of Southeast Asian countries.

It seems that due to the similarity of the subject of study constitutionalists conducting comparative studies on constitutional systems, should also reach for the achievements of political science, and political scientists in analyzing political systems should use the doctrine of constitutional law. ${ }^{14}$ As the experience of scientists from Western European countries and the United States shows, the border between the areas of interest of these sciences is becoming less clear, only the research methodology remains different.

Polish researchers also seem to be turning their attention to the Far East. However, in addition to individual and fragmentary publications on the subject, the constitutional systems of states of the largest continent in the world are still a terra incognita for most, and not only Polish constitutionalists.

For some time, especially in Western Europe, a growing interest in "non-classical" directions of research can be observed, including in particular the constitutional systems of Asian countries. ${ }^{15}$ The conferences organized by the European Asso-

7 csaw.ug.edu.pl/ (accessed: 16.04.2020).

8 www.ue.wroc.pl/biznes/5810/centrum_badan_azji_i_pacyfiku.html (accessed: 16.04.2020).

9 www.swps.pl/nauka-i-badania/materialy-ccaw (accessed: 16.04.2020).

10 zaw.uni.lodz.pl/?lang=en_gb (accessed: 16.04.2020).

11 osa.uni.lodz.pl/ (accessed: 16.04.2020).

12 isppan.waw.pl/strony-www-projektow-naukowych/centrum-badan-azji-i-pacyfiku/ (accessed: 16.04.2020).

13 www.polska-azja.pl/ (accessed: 16.04.2020).

14 T. Mołdawa, J. Zaleśny, Parlamentaryzm w świecie wspótczesnym. Między ideq a rzecsyynistościa, Warszawa 2011, p. 8.

15 The European Association for Southeast Asian Studies (EuroSEAS) was founded in 1992 and is the largest organization in the world gathering scientists in research on Southeast Asia. EuroSEAS also aims at stimulating scientific cooperation in Europe in the field of research in Southeast Asia. The main areas of interest of EuroSEAS members are the humanities and social sciences, covering all fields of these scientific disciplines (from archeology to economics, including anthropology, linguistics, history of art, literature, theatre, religious studies and political sciences). The main manifestation of EuroSEAS's activity are international and interdisciplinary conferences held at the beginning every three years gathering hundreds of specialists from around the world enabling them to establish cooperation and exchange views. So far, conferences have been held in Leiden 
ciation for Southeast Asian Studies, the International Asian Congress held every year in Torun and recently established Association for Asian Constitutional Studies show the increasing and incessant interest of researchers representing social sciences in Southeast Asia. The multitude of issues, their diversity as well as the ever-changing legal environment and political conditions prove that this research field will be able to be explored for a long time. However, it is impossible not to notice that - as far as the Polish scientific community is concerned - there are no coordinated activities or large-scale research projects enabling comprehensive, interdisciplinary research on constitutional systems and the practice of functioning of the countries of the region.

(1995), Hamburg (1998), London (2001), Paris (2004), Naples (2007), Göteborg (2010) and Lisbon (2013), respectively. Next meetings already in a two-year cycle took place in Vienna (2015), Oxford (2017) and Berlin (2019). Over 500 people representing all major academic centres from around the world (except South America) participated in the conferences I had the pleasure to attend (Vienna, Oxford). That obviously shows how interesting Southeast Asia is as the research area. In recent years, a change in the formula for running panels during conferences should be noted. During the meeting in Vienna (2015), despite the presence of guests representing academic centres from Southeast Asia, the papers were delivered mainly by European researchers - recognized and experienced specialists in political science (originating in countries of former colonizers of the region), authors of many publications on the political issues of the countries of the region. A different concept was adopted at Oxford (2017). While the panel moderators were still recognized specialists in a given field of research, usually still of European provenance, the persons presenting the papers or the results of the conducted research (and mostly preliminary theses) - were mostly $\mathrm{PhD}$ students of these institutions. In addition, as in Vienna, in most cases it was difficult to find a common denominator for all the speeches presented in a given panel due to the very broad approach to the topic. The above indicates how great interest in the functioning of ASEAN countries is expressed by European researchers, as well as the absence of representatives of Central and Eastern European countries in conducting research in this field (I was the only speaker representing this region in both Vienna and Oxford in terms of broadly understood social sciences).

At the same time in Poland (Toruń) the International Asian Congress has been organized. It takes place in a similar form every year and has been integrating researchers, experts, politicians and diplomats for twelve years, constituting the largest event devoted to Asia in Central Europe.

In this context, the another undertaking should be noted known as Asian Constitutional law Forum which aims at providing a venue for distinguished academics to share their thoughts and opinions on Asian constitutional law, to expand research networks, and to encourage collaboration. The first Forum was held at the Seoul National University, Korea in 2005. At the close of the forum in 2015, participants expressed a desire to set up a new Association for Asian Constitutional Studies, and Professor Andrew Harding (National University of Singapore) was asked to chair a preparatory committee to set up the new Association. The Association for Asian Constitutional Studies co-host the last Forum in 2019 in Hanoi, Vietnam. Again, during this two-day event, I was the only representative of a Central and Eastern European country. Also in case of this conference, the deliberations - due to the number of participants and the variety of topics - were divided into parallel panels, which excluded participation in all discussions and listening to all papers. Suffice it to say that nearly 80 articles were included in the post-conference publication. 


\section{ASEAN countries: constitutions without constitutionalism?}

The phrase "constitutions without constitutionalism" has been used by various authors to describe the state of constitutional law in Africa, the Middle East and Latin America at various points in time. For significant periods, the constitutional circumstances of many Asian countries may also be aptly summarised by "constitutions without constitutionalism". Just as in the daily life of individuals, it is relatively easy to say something or make a promise, but more difficult to translate what is said or promised into action and reality, so in the political and legal life of nations, it is relatively easy to make a constitution, but more difficult to put it into practice, to implement it and be governed by it - which is what "constitutionalism" is about. There is therefore nothing surprising about the phenomenon or "syndrome" of "constitutions without constitutionalism," particularly in developing countries to which Western ideas, theories and institutions of constitutionalism have been transplanted in the course of the last two centuries. ${ }^{16}$

Constitutionalism in Europe is homogenous in respect of some core values and principles, at least as far as the member states of the European Union are concerned. But the constitutional traditions in Europe are nonetheless very diverse with the written and unwritten constitutions, monarchies and republics, unicameral and bicameral parliaments, etc. However, constitutional diversity is much greater and much more substantial in Asia, particularly in Southeast Asia. ${ }^{17}$

Southeast Asia is a very interesting region for researchers of constitutional systems, although quite undiscovered by Polish scholars of this branch of law. This area includes the Indo-Chinese Peninsula, Malay Archipelago and the Philippines, including the following countries: Myanmar, Thailand, Cambodia, Laos, Vietnam, Malaysia, Singapore, Indonesia, East Timor, Brunei and the Philippines. They occupy an area of approximately 4.495 million square kilometers, with a population exceeding 550 million people (estimate for 2004). By comparison, according to the statistics, Europe had at that time 731 million people in the area of 10.5 million square kilometers. The region diverse ethnically, religiously, culturally, and economically and has a very rich history. These factors, along with experiences of the colonial period provide that the states of Southeast Asia are very interesting, but also very difficult area of research.

Proper history of constitutional democracy of independent Southeast Asia countries started during the Cold War, when the region was also an area of abrasion

16 A.H.Y. Chen, The achievement of constitutionalism in Asia: moving beyond 'constitutions withoutconstitutionalism' [in:] Constitutionalism in Asia in the Early Twenty-First Century, ed. A.H.Y. Chen, Cambridge 2014, pp. 1-31.

17 J. Menzel, Constitutionalism in Southeast Asia: some comparative perspectives [in:] Constitutionalism in Southeast Asia, vol. 3, Cross-Cutting Issues, eds. C. Hill, J. Menzel, Singapore 2010, p. 14. 
of two warring blocks. Decolonization and democratization in the region began after the Second World War and lasted almost until the first decade of the twenty-first century, but many still do not believe that these processes have been completed. At this time, these countries guided by historical experience, professed by the majority of the public religion, trade and economic connections with the former colonizers and the neighboring countries, made the selection intake system of government and the guiding principles of the state. Therefore, at present it is very difficult to find a common denominator for the comparative study of legal and constitutional systems of these countries.

As indicated, the region covers the territory of 11 countries, with constitutions which have been formed since 1945 (Indonesia) till 2017 (Thailand). The normative acts, at present constitute within the area of Southeast Asia: one absolute monarchy (Brunei), three communist republics (Myanmar, Laos and Vietnam), three constitutional monarchies (Thailand, Cambodia, Malaysia) and four democratic republics (East Timor, Singapore Indonesia, the Philippines). It should be noted that you cannot put the thesis that colonial experience influenced in the same way the selection of systems adopted in the country after gaining independence. While the influence of legal traditions of former colonists is shown in the adopted legal systems of former colonies, this rule does not apply to the implementation of the constitutional system of these countries. Four of the region's countries are former British colonies (Singapore, Brunei, Malaysia, Myanmar), four - French colonies (Thailand, Cambodia, Laos, Vietnam), the Philippines freed themselves from the influence of Spain, and East Timor from the dominion of Portugal and the Netherlands, while Indonesia was a Dutch colony. At the same time, Brunei - despite the strong British influence - has not introduced a democratic form of government, and the Philippines - anterior Spanish colony - in 1987 adopted a constitution modeled heavily on the constitution of the United States. The East Timor - the Portuguese colony - adopted institutions and solutions specific to the Portuguese constitution.

Analysis of institutional arrangements adopted in the constitutions of countries of the region allows to distinguish two types of government systems, prevailing characteristic of this area, namely the parliamentary and presidential systems. The first one was adopted in Malaysia, Singapore, ${ }^{18}$ Thailand and

18 Researchers disagree as to what government system is operating in Singapore. Some researchers believe that we are dealing here with a semi-presidential system (Y.-S. Wu, Clustering of semi-presidentialism: A first cut [in:] R. Elgie, S. Moestrup, Y.-S. Wu, Semi-Presidentialism and Democracy, London 2011, pp. 21-41) or presidential (R. Elgie, The semi-presidential one, http://www.semipresidentialism.com/, accessed: 7.07.2017), others tend to claim that it is still a parliamentary system of government (J. Blondel, The national executives in East and Southeast Asia [in:] Democratization, governance and regionalism in East and Southeast Asia: a comparative study, ed. I. Marsh, Abingdon, Oxon 2006, pp. 89-123). In my opinion, the constitutional changes introduced in 2017 limit the 
Timor-Leste ${ }^{19}$ and formally in Vietnam and Cambodia and Laos (the constitution was modeled on a Vietnamese one). However, the presidential system of government was adopted by Indonesia and the Philippines. At the same time, differences exist also within the parliamentary system of government. The unicameral parliament is in Singapore and East Timor, Laos and Vietnam. However, the constitutions of Malaysia, Thailand and Cambodia form a bicameral structure of the legislature.

It is believed that the countries of Southeast Asia have no sense of national identity and existence of boundaries between nations. The diversity of cultural division and historical experiences of this region makes studying of constitutional systems of Southeast Asia countries difficult and complex. Professor K. Tan of the National University of Singapore believes that, given the great wealth of historical and cultural heritage of the region, comparative legal study conducted by the constitutionalists should focus on three issues, namely colonialism, communism and evolution (revolution) in order to explain and describe the process of constitutions adoption in this part of the world. ${ }^{20}$

It should be emphasized, however, that it is extremely difficult to determine any common denominator for a group of countries in this region, as already indicated in the literature on the subject. ${ }^{21}$ Southeast Asia is probably the most complex region in the world. There are about 5.000 languages, or half of all the world's languages, and all world religions. This is where you can observe the special overlap of various influences of nearby civilizations - Indian, Chinese, and Muslim - on the local substrate, which still remains viable and is more and more visible in almost all countries of the region..$^{22}$ Despite the conspicuous similarities regarding the adopted model of the constitutional system, ${ }^{23}$ the practice of the functioning of individual institutions, and in particular social and political factors affecting the way they are adapted, influence the emergence of observable discrepancies in the adopted political systems. Therefore, these countries differ in history, dynamics of political system changes, cultural, religious and ethnic structure of societies, size of the state and its organiza-

political power of the president even more, bringing the Singapore government system closer to the parliamentary (chancellor) system, not the presidential one.

19 It is also characterized as semi-presidential: L.M. Beuman, Political Institutions in East Timor: Semi-Presidentialism and Democratisation, Abingdon, Oxon 2016, p. 3.

${ }^{20}$ K. Tan, Jiunn-Rong Yeh, Chao-Ju Chen, Li-Ju Lee, Wen-Chen Chang, History and Culture: Complexities in Studying Southeast Asian Constitutionalism, "National Taiwan University Law Review", September 2010, vol. 5, no. 2, p. 189.

21 See: A.W. Jelonek, $W$ strone nieliberalnej demokracji, Warszawa 2002, p. 7.

22 See: Zrozumié Azje, dyskutują: Maria Krzysztof Byrski, Krzysztof Gawlikowski, Henryk Lipszyc, Stanisław Zapaśnik, Jacek Borkowicz, Wojciech Górecki, "Więź” 2000, nr 7, http:// labo-old.wiez.pl/teksty.php?zrozumiec_azje\&p=4 (accessed: 19.08.2016).

23 For example, the parliamentary cabinet system of government based on the Westminster model was adopted in Singapore and Malaysia, as well as in Thailand in the 2007 constitution. 
tion, form of government, etc. Nevertheless, this diversity, so characteristic of this region, should be extremely inspiring for comparatists.

The dynamics of constitutional changes is another characteristic feature of the region. All Southeast Asian countries are also characterized by the ease of making changes to the political system (not necessarily associated with a formal change to the Basic Law, but also as a result of revising its provisions, as is the case in the constitutional system of Malaysia and Singapore). Changes in constitutional orders are illustrated in the table 1.

Table 1. Constitutional changes in Southeast Asia

\begin{tabular}{|l|c|c|c|}
\hline \multicolumn{1}{|c|}{ Country } & $\begin{array}{c}\text { Date of adoption of the } \\
\text { first constitution }\end{array}$ & $\begin{array}{c}\text { Number of constitutions } \\
\text { adopted in 1898-2017 }\end{array}$ & $\begin{array}{c}\text { Date of last } \\
\text { revision }\end{array}$ \\
\hline Brunei & 1959 & 1 & 2004 \\
\hline Cambodia & 1947 & 5 & 1999 \\
\hline East Timor & 2002 & 1 & - \\
\hline Indonesia & 1945 & 4 & 2002 \\
\hline Laos & 1947 & 2 & 2003 \\
\hline Malaysia & 1957 & 1 & ongoing revision \\
\hline Myanmar & 1947 & 3 & 2008 \\
\hline Philippines & 1898 & 6 & ongoing revision \\
\hline Singapore & 1959 & 1 & 2017 \\
\hline Thailand & 1932 & 20 & 2003 \\
\hline Vietnam & 1946 & 4 & \\
\hline
\end{tabular}

Source: A. Michalak, Znaczenie zasady dwnizbowości w praktyce ustrojowej mybranych demokraciji Azjï Potudniowo-Wschodniej (Malerja, Singapur, Tajlandia, Timor Wschodni), Łódź 2019, s. 11.

Contemporary researchers of constitutional systems refer to the notion of incomplete democracy, meritocracy, Confucian democracy, Asian democracy, Thaistyle democracy, hybrid regime, friendly authoritarianism in relation to the region we are interested in. Cultural and social changes currently taking place in Southeast Asia are ambiguous and their direction is difficult to predict. However, the development of state forms that differ significantly from Western, but equally modern, is very likely there. These changes will undoubtedly be of great importance in the future for the development of democracy in these countries, and maybe also in other parts of the world. Therefore, you cannot remain indifferent to them.

In my research to date, I have analyzed the constitutional systems of Malaysia and Singapore, i.e. countries that have adopted a parliamentary cabinet government system modeled on the Westminster model. Not without significance was the fact that these countries have a common history related not only to British 
colonialism, but also relating to the short period of common statehood, the relics of which can be found e.g. in the legal system of Singapore, some of which are still normative acts adopted in the times: colonial, Singapore's membership of Malaysia, and finally the provisions of the Malaysian constitution. In addition, in my opinion, East Timor, which adopted a constitution strongly modeled on the Portuguese Basic Law, remains an important reference point for Singapore. These countries share not only a small territory, but also a relatively short period of independence. For both countries, issues related to the religious structure of society are of significant importance. For Singapore, religious diversity has become one of the reasons for separation from the Malaysian Federation. In case of East Timor, cultural and religious differences were the driving force behind the efforts to free themselves from the occupation of Indonesia. In turn, Thailand, in comparison to the above-mentioned countries, is distinguished by the fact that it has never been colonized in a formal sense. However, when adopting both the first constitution in 1932 and the constitution of 2007, it used the Westminster model. This country is also distinguished from the others by the tendency to change the constitutional order frequently and to adopt further basic laws. However, as Malaysia, despite these normative changes, Thailand remains a constitutional monarchy. At the same time, in both countries the head of state plays an important role as the religious leader of the nation.

At the moment - especially in Poland and Europe - there is a discussion about desirable and necessary changes in the constitution, common and non-definable democratic values, the scope of omnipotence of the authorities selected through free elections. Changes, that are to respond to current political and social problems of the nations, make up the European Union. We are observing the crisis of liberal democracy and it may be time to start the debate on whether liberalism without democracy or democracy without liberalism awaits us. ${ }^{24}$ The analysis of the functioning of the democratic system adapted in the constitutions of Southeast Asian countries in accordance with the civilization specificity of the value systems of those communities (the concept of "Asian values") can be an interesting contribution and a background to reflection on the future of European democracies.

Any discussion of respect for human rights in postcolonial Asian countries from the perspective of Western civilization faces many obstacles, in particular those related to existing differences, or even cultural barriers and different traditions. Postcolonial states, despite remaining colonial remains - visible e.g. in the legal system, which still contains normative acts adopted before gaining sovereignty - very strongly resist the adoption of the universal catalogue of human rights set out in UN pacts, as well as the application of standards in their observance, which

24 See: W. Case, Democracy's mixed fortunes in Southeast Asia. Torpor, change, and trade-offs [in:] Routledge Handbook of Southeast Asian Democratization, ed. W. Case, London 2015, p. 3. 
would be consistent with those developed within the UN. This is not a special feature of Asian democracies. A discussion on the legitimacy of the universal (global) catalogue of human rights has been underway since the 1970s. The most radical opponents see it as a new form of colonialism.

The transfer of sovereignty to the nation, the implementation of values arising from the rule of law and the development of individual fundamental rights are changes that in the twentieth century were the pillars of the modernization of the constitutional systems of postcolonial Asian countries. However, not all of them have adopted and ratified international treaties providing institutional guarantees for respecting the human rights listed therein. In particular, Singapore, Malaysia and Myanmar have not become signatories to these pacts, and in the long run have begun to create alternative systems and mechanisms to protect human rights. In 2009, these countries led to the creation of the Intergovernmental Commission on Human Rights (AICHR) as part of the Association of South East Asian Nations (ASEAN).

Despite pressure from many international organizations, which negatively assess the practice of the operation of the governments of most Asian countries (as well as AICHR) in this respect, there is no indication that this situation will change in the near future. This is obviously influenced by many factors, but the most important of them - it seems - remains the above-mentioned doctrine of the so-called Asian values. Propagating it meant that the concept of universalization of international human rights standards in Asian postcolonial countries was replaced by an approach that promotes the separate culture, tradition and civilization of these nations, which - in the opinion of the rulers - prevents the adoption of an identical international catalogue, standards and mechanisms for the protection of human rights. It should be emphasized that - in my opinion - in the initial phase after independence, actions aimed at "globalization" of the colonial states' approach to human rights could be observed. A clear turn of these trends occurred in 1993 at the World Conference on Human Rights in Vienna, when the Foreign Minister of the Republic of Singapore stated that attempts to create the perfect universal catalogue of human rights are harmful because they lead to blur of real diversity. This position was supported in particular by the Chinese delegation, whose members argued that, in accordance with the cultural traditions of Asian civilizations, citizens must put the good of the state above their own. That is why the idea of an individual catalogue of inviolable, fundamental human rights is alien to these societies. ${ }^{25}$

Cultural differences between East Asia and Western countries relate to many aspects, secondary and such basic issues as the comprehension of man and his place

25 A. Michalak, Przestrzeganie praw cztowieka w mybranych państwach Azji postkolonialnej - aktualne problemy, "Przegląd Prawa Konstytucyjnego" 2015, nr 1, pp. 115-134. 
in the world, value structures, principles of social and political life organization, etc. For these considerations, it is also extremely important to state that Western societies and Southeast Asia have different types of organizational structure. The first are organized "horizontally" and are based on the assumption of equality of people and partner relations between individuals. The second one is characterized by the "vertical" construction, i.e. the hierarchical social order based on the "higher" "lower" rank ratio. The status of an individual is determined by his place within the group and the position of the group in society. An individual is guilty of respect and obedience to persons in a higher position. On the other hand, senior units have a managerial and protective role. Leaders must have the constant support of subordinates and cannot impose anything arbitrarily, because the highest ideal is to maintain harmony and the good of the group. ${ }^{26}$

At the same time, grassroots social movements that have been developing in recent years, especially visible in Singapore, contesting the political system (and especially the shape of electoral law), demanding the observance of constitutionally guaranteed rights and freedoms (including freedom of expression) and abolishing the death penalty, cannot be overlooked. From our perspective, these changes seem insignificant, but in a country where, for the sake of development, security and prevention of the propagation of the idea of communism, some civil liberties and freedoms were devoted (i.e. property law, prohibition of torture, including punishments that violate dignity) may suggest the need to verify the current approach of the authorities to civil liberties.

Overall speaking, the achievement of constitutionalism in Asia since the end of the World War II, and particularly since the 1980s, has been considerable and significant. Although some scholars associate the Western form of liberal constitutional democracy with imperialism and global capitalism, the historical evidence is that constitutionalism has appealed to Asian peoples in their struggles for emancipation and justice, and has also been embraced by the political elite in many Asian countries as a political order that is both morally legitimate and practically appropriate for local conditions. If progress is at all possible in human history, then the achievement of constitutionalism in the governance of human societies may be regarded as a significant element and sign of such progress. Although the "end of history" is not yet in sight. ${ }^{27}$

Nevertheless, even after such fragmentary research on the constitutional systems of the ASEAN countries as described in my two monographs, I think we should look more closely at various specific legal institutions implemented in this region.

\footnotetext{
26 M. Kosmala, Dwie cywilizacje - dwa systemy wartości, dwie wizje praw çłowieka, "Azja-Pacyfik" 2004, t. 7, p. 25.

27 See, e.g., J. Tully, The imperialism of modern constitutional democracy [in:] The Paradox of Constitutionalism: Constituent Power and Constitutional Form, eds. M. Loughlin, N. Walker, Oxford 2007, p. 315.
} 
First of all, I mean all instruments and procedures - developed especially in Singapore's legal system - guaranteeing equal rights for followers of different religions (procedure for choosing a president, Presidential Council for Minority Rights). They are obviously not perfect (just like the practice of using them). Nevertheless, they are an example of legislation regulating in a detailed way, and in some respects even a meticulous implementation of the principle of equality common in Western countries.

For all scholars of parliamentary studies, alternative methods of shaping the composition of the unicameral parliament should be extremely interesting - again adopted in Singapore - ensuring to some extent the diversity of views presented during parliamentary debates and the participation when discussing alternative solutions. The Singapore Parliament comprises four categories of Members, which are: 1) elected Members from Single-Member District; 2) elected Members from Group Representation Constituency; 3) Non-Constituency Members; ${ }^{28}$ and 4) Nominated Members. ${ }^{29}$ Both Non-Constituency Members and Nominated Members have voting rights in Parliament. However, they cannot vote on budget or appropriation bills, bills to amend the Constitution, motions of no confidence in the government, and motions to remove the President of Singapore from office.

In addition, although East Timor is a democracy at the beginning of its democratic development for most so-called Western countries, and the level of education and organization of society does not match European conditions, it is interesting how territorial structures and the involvement of local leaders were there used to exercise state power and implement the organization of state. The modern state, based on democratic principles, has in practice recognized the value of "traditional" authorities in various situations - both in political (passing the legal foundations for indigenous leaders to rule on the level of local communities in the suku and aldeia) and judicial matters (authorities allowed dissolution of local disputes based on the so-called tara bandu). These processes especially in the context of the principle of subsidiarity that is so widely spread in Europe are extremely interesting.

As far as I am concerned, the matter of great importance for comparative studies is the development of Thai constitutional provisions regarding the provisions

\footnotetext{
28 The Constitution stipulates that up to nine Non-Constituency Members may be appointed from among unsuccessful opposition candidates who obtained the highest percentage of votes in an election (so-called best losers). The appointment of Non-Constituency Members is to ensure that the views of the opposition can be expressed in Parliament.

29 The Constitution also empowers the President of Singapore to appoint up to nine Nominated Members from among non-partisan individuals with distinguished performance in their respective fields, after taking into account the recommendation of the Special Select Committee chaired by the Speaker of Parliament. Nominated Members are appointed for a term of two and a half years, and their appointments represent an effort to have a wider representation of the community views in the legislature.
} 
which allows the King to use his royal prerogative in line with the traditional rule in cases where no existing laws are applicable. ${ }^{30}$ This was introduced as Article 7 in the 2007 constitution. In the constitutional draft approved in the referendum in 2016, Article 5 authorised the Constitutional Court to hold a special meeting with political leaders to deal with any severe crisis or impasse. That regulation was changed as advised by the Royal Household Bureau. Nevertheless, the abovementioned provisions show the development of procedure (or constitutional practice) regulating how to deal with the constitutional crisis (and the definition of such a crisis itself).

\section{Conclusion}

Lately two books were issued. The future is Asian by Parag Khanna ${ }^{31}$ who stated that: "in the $19^{\text {th }}$ century, the world was Europeanized. In the $20^{\text {th }}$ century, it was Americanized. Now, in the $21^{\text {st }}$ century, the world is being Asianized." The second one is The end of the Asian Century by Michael R. Auslin, ${ }^{32}$ who argues that far from being a cohesive powerhouse, Asia is a fractured region threatened by stagnation and instability. He provides a comprehensive account of the economic, military, political, and demographic risks that bedevil half of our world, arguing that Asia, working with the United States, has a unique opportunity to avert catastrophe - but only if it acts boldly.

Although, we can point out that the authors of these publications present different perspectives, it is hard not to notice that their theses completely contradict each other. For the comparatist it would be more than interesting to see which of the above-cited authors was right. At the same time, the above-mentioned examples of the uniqueness of constitutional regulations and instruments introduced in the ASEAN countries justify the thesis about the need for further research in this region, that application effects cannot be excluded a priori.

\footnotetext{
30 The Constitution is the supreme law of the State. The provisions of any law, rule or regulation or any acts, which are contrary to or inconsistent with the Constitution, shall be unenforceable. Whenever no provision under this Constitution is applicable to any case, an act shall be performed or a decision shall be made in accordance with the constitutional conventions of Thailand under the democratic regime of government with the King as Head of State.

31 P. Khanna, The future is Asian, Simon \& Schuster, New York 2019.

32 M.R. Auslin, The end of the Asian Century, Blackstone Audio, Inc., 2017.
} 


\section{STRESZCZENIE}

\section{MIEূDZY EKLEKTYZMEM A UNIKALNOŚCIĄ - KILKA UWAG NA TEMAT SYSTEMÓW KONSTYTUCYJNYCH PAŃSTW ASEAN Z PERSPEKTYWY POLSKIEGO KONSTYTUCJONALISTY PORÓWNAWCZEGO}

Prowadzenie badań prawno-porównawczych wymaga nie tylko profesjonalnych kompetencji dotyczących znajomości języków obcych, lecz również opanowania metod prowadzenia takich badań, przede wszystkim zaś pobytów na stażach zagranicznych i licznych dyskusji z ekspertami z różnych państw. Nie można bowiem podejmować tego rodzaju badań wyłącznie na podstawie, nawet najbardziej uważnie zebranych, zagranicznych źródeł i literatury normatywnej. Niewidoczna, jak również nieznana ani niekwestionowana, niewidzialna konstytucja stanowi poważne wyzwanie dla modelu konstytucyjnego, interpretacji konstytucji i jej zmiany. Ta perspektywa, która nie może być pominięta, pozostawia badaczowi możliwość stawiania pytań o charakter prawa wyższego rzędu, granice kodyfikacji, jak również niezbędne i wystarczające warunki dla konstytucjonalizmu - kluczowe kwestie dotyczące pełnych badań w prawie konstytucyjnym porównawczym.

Azja Południowo-Wschodnia jest bardzo interesującym regionem dla badaczy systemów konstytucyjnych, chociaż nieco nieodkrytym przez polskich naukowców zajmujących się tą gałęzią prawa. Region jest zróżnicowany pod względem etnicznym, religijnym, kulturowym, ekonomicznym i ma bardzo bogatą historię. Czynniki te, wraz z doświadczeniem okresu kolonialnego, sprawiają że państwa Azji Południowo-Wschodniej są bardzo interesującym, a jednocześnie niezwykle trudnym obszarem badawczym. Przykłady unikalności regulacji i instrumentów konstytucyjnych wprowadzone w państwach ASEAN, które zostały wskazane w artykule, uzasadniają tezę o potrzebie prowadzenia dalszych badań w tym regionie, a skutki ich stosowania nie moga zostać odrzucone a piori. 